medRxiv preprint doi: https://doi.org/10.1101/2021.05.18.21257110; this version posted May 19, 2021. The copyright holder for this preprint (which was not certified by peer review) is the author/funder, who has granted medRxiv a license to display the preprint in perpetuity.

All rights reserved. No reuse allowed without permission.

\title{
1 Assessment of the infectious threshold of SARS-CoV-2 in primary airway epithelial cells
}

2 Running Title: SARS-CoV2 isolation in HAE and Vero E6

3 Manel Essaidi-Laziosi ${ }^{1}$, Francisco Javier Perez Rodriguez ${ }^{2}$, Pascale Sattonnet-Roche ${ }^{2}$, Nicolas

4 Hulo $^{3}$, Frederique Jacquerioz ${ }^{2}$, Laurent Kaiser ${ }^{2}$ and Isabella Eckerle ${ }^{1,2}$

5

$6{ }^{1}$ Department of Microbiology and Molecular Medicine, University of Geneva, Geneva,

7 Switzerland

$8 \quad 2$ Division of Infectious Diseases, Geneva University Hospitals, Geneva, Switzerland.

$9 \quad{ }^{3}$ Service for Biomathematical and Biostatistical Analyses. Institute of Genetics and Genomics,

University of Geneva, Geneva, Switzerland

Corresponding author: Isabella Eckerle, Geneva Centre for Emerging Viral Diseases, Geneva University Hospitals,

Geneva, Switzerland.Geneva University Hospitals, Rue Gabrielle-Perret-Gentil 4, 1205 Geneva, Switzerland. Tel:

+41223729820; FAX: +41223724097; Email: isabella.eckerle@unige.ch

15

Infectiousness

\section{Key words}

\section{SARS-CoV-2}

COVID-19

Virus isolation

Alternate corresponding author. Manel Essaidi-Laziosi, Department of Microbiology and Molecular Medicine, Faculty of Medicine of Geneva, University of Geneva, Geneva, Switzerland. Rue Michel-Servet 1, 1205 Geneva. Tel. +41223795528, Email: Manel.Essaidi@unige.ch

Airway epithelium

NOTE: This preprint reports new research that has not been certified by peer review and should not be used to guide clinical practice. 
medRxiv preprint doi: https://doi.org/10.1101/2021.05.18.21257110; this version posted May 19, 2021. The copyright holder for this preprint (which was not certified by peer review) is the author/funder, who has granted medRxiv a license to display the preprint in perpetuity.

All rights reserved. No reuse allowed without permission.

\section{Abstract}

27 Comparison of virus isolation success from clinical samples across a range of viral loads

28 inoculated in parallel on Vero E6 and human airway epithelia (HAE) showed lower success of

29 virus isolation in HAE, suggesting an overestimation of actual infectiousness in humans using

30 Vero E6 cell lines, commonly considered as reference.

31 
medRxiv preprint doi: https://doi.org/10.1101/2021.05.18.21257110; this version posted May 19, 2021. The copyright holder for this preprint (which was not certified by peer review) is the author/funder, who has granted medRxiv a license to display the preprint in perpetuity.

\section{Main text}

Understanding the window of Severe Acute Respiratory Syndrome coronavirus 2 (SARS-CoV2) infectiousness is essential for the control of the coronavirus disease 19 (COVID-19) pandemic. Thanks to its high sensitivity and rapidity, real time RT-PCR remains the gold standard for diagnosing SARS-CoV-2. However, detection of viral RNA by this method does not necessarily equate with the presence of infectious viral particles, the requisite for transmission.

Although resource-intensive (as dependent on biosafety level-3 facilities) and not suitable for routine diagnostic purposes, inoculation of patient's specimens on cultured cells is to date the only method to confirm presence of infectious SARS-CoV-2 in a sample. A number of studies highlighted two determinants of the presence of infectious particles: SARS-CoV-2 RNA copy numbers (RNAc) per $\mathrm{mL}$ in the original specimens, as determined by RT-PCR, and the symptom duration. The probability of isolating viable virus hence appears to be drastically reduced below 5.4-7 $\log _{10} \mathrm{RNAc} / \mathrm{mL}$, and after more than one week of symptoms [1-3].

The vast majority of these investigations used Vero E6 cells, derived from the kidney of an African Green Monkey, although several other conventional Human cell lines, such as Caco2 (colorectal adenocarcinoma) and Calu3 (lung cancer cells) were also found to be susceptible [4]. As they are interferon-production deficient [5] and express the virus receptor [6], Vero E6 cells are highly susceptible to SARS-CoV-2 and thus are the most widely used reference cell line for isolation. However, these cells do not mimic the in vivo situation of the SARS-CoV-2 entry site, which is the human respiratory tract. The use of reconstituted human primary airway epithelial cells (HAE) better reflects SARS-CoV-2 infection characteristics in vivo.

To assess of the threshold for the presence of infectious virus in this more relevant model system, we compared virus isolation success from clinical samples across a range of viral loads 
medRxiv preprint doi: https://doi.org/10.1101/2021.05.18.21257110; this version posted May 19, 2021. The copyright holder for this preprint (which was not certified by peer review) is the author/funder, who has granted medRxiv a license to display the preprint in perpetuity.

All rights reserved. No reuse allowed without permission.

(VLS) inoculated in parallel on Vero E6 and HAE. We found that this threshold is higher in HAE compared to Vero E6, suggesting the presence of infectious virus as determined by Vero E6 would not necessarily be sufficient to lead to an infection in HAE.

In this study, we used nasopharyngeal swabs collected in viral transport medium from symptomatic adult individuals presenting at the outpatient testing center of the University Hospitals of Geneva, spanning the first pandemic wave in spring 2020 and a second pandemic wave in fall 2020, that tested positive for SARS-CoV-2 by RT-PCR (Cobas ${ }^{\circledR}$ SARS-CoV-2 Test, Cobas 6800, Roche, Switzerland). All samples were collected from patients within the first 5 days post onset of symptoms (dpos), diagnosed between April and September 2020. All viruses circulating during the investigated time period were characterized by the D614G mutation, but no variants of concern were circulating in Switzerland during that time. VLs were calculated for the E gene target as previously described [7]. In order to avoid loss of infectivity, all samples were frozen at $-80^{\circ} \mathrm{C}$ after diagnostic testing. Their inoculation was performed immediately after a single thawing (there were no repeated freeze-thaw cycles). Regarding virus isolation, $100 \mu \mathrm{l}$ of the original clinical sample was inoculated in parallel on Vero E6 cells grown in 48 well plates and in HAE (MucilAir ${ }^{\mathrm{TM}}$ commercially available, Epithelix SARL), with an approximate number of cells for both culture systems of $2 \mathrm{E}+05$ cells per well. Infections were performed at $37^{\circ} \mathrm{C}$ under a $5 \% \mathrm{CO}_{2}$ atmosphere as previously described $[8,9]$. Viral replication was assessed by quantitative RT-PCR from RNA extracted from the supernatant collected at 1 hour post infection (hpi) for Vero E6 and from apical tissue washes 3hpi for HAE, and at the end of the experiment 6 days post infection (dpi). Successful virus isolation was determined by at least $3 \log 10$ folds increase of RNAc between baseline and $6 \mathrm{dpi}$.

In total, 38 primary clinical specimens were inoculated in parallel, with a VL ranging from 5.7$9.0 \log _{10}$ SARS-CoV-2 RNAc/mL in the original sample. The overall frequency of successful virus 
medRxiv preprint doi: https://doi.org/10.1101/2021.05.18.21257110; this version posted May 19, 2021. The copyright holder for this preprint (which was not certified by peer review) is the author/funder, who has granted medRxiv a license to display the preprint in perpetuity.

All rights reserved. No reuse allowed without permission.

80

81

82

84

85

isolation was 27/38 in Vero E6 and 12/38 in HAE (Figure 1A and Table S1). No growth in either cell culture system was observed in samples below $5.8 \log _{10} \mathrm{RNAc} / \mathrm{mL}$. The lowest VL from which infectious virus could be isolated in Vero E6 was $5.9 \log _{10} \mathrm{RNAc} / \mathrm{mL}$ and $6.3 \log _{10}$ $\mathrm{RNAc} / \mathrm{mL}$ for HAE (Figures $1 \mathrm{~A}$ ). Although two samples with rather low viral load of 6.3 and 6.5 $\log _{10} \mathrm{RNAc} / \mathrm{mL}$ showed successful isolation in $\mathrm{HAE}$, consistent isolation of virus was only observed in samples with a VL of $7.7 \log _{10} \mathrm{RNAc} / \mathrm{mL}$ and higher. Using Probit analysis, the probability of a sample being infectious in Vero E6 and HAE was below 5\% when VL was lower than 5.5 and $6.5 \log _{10}$ SARS-CoV-2 RNAc/mL, respectively ( $p$ value $<0.05$ ). No correlation was found between the number of dpos within the first 5 dpos and successful viral growth in both models (in order to increase the likelihood of infectious virus presence, only samples from patients $\leq 5$ dpos were selected) (Table S1).

Upon successful isolation, the virus showed replication to higher viral loads in Vero E6 (mean VL of $12.1 \log _{10} S A R S-C o V-2 R N A c / m L, S D \pm 0.7$, range 11.1-14.06) compared to HAE (mean VL of $10.3 \log _{10}$ SARS-CoV-2 RNAc/mL, SD \pm 1.4 range 6.1-11.4) at the end of the experiment (6 dpi, Figure 1B). In conclusion, upon comparative virus isolation, we could recapitulate findings from earlier studies on Vero E6 with successful virus isolation in a similar range as previously reported. In the HAE model, however, virus isolation was only consistently successful in samples with a VLs of $\geq 7.7 \mathrm{RNAc} / \mathrm{mL}$ (Figure $1 \mathrm{~A}$ ), but there were two outliers of successful isolation with a much lower VL. In conclusion, Vero E6 cells are shown to be more permissive for SARS-CoV-2 isolation and yield virus isolates from samples with lower VLS than HAE. Furthermore, upon successful isolation, SARS-CoV-2 replicates in Vero E6 to higher virus titers than in HAE.

Lower success of virus isolation in $\mathrm{HAE}$, and thus a higher amount of infectious virus particles needed to start an infection, could hint towards an overestimation of actual infectiousness in 
medRxiv preprint doi: https://doi.org/10.1101/2021.05.18.21257110; this version posted May 19, 2021. The copyright holder for this preprint (which was not certified by peer review) is the author/funder, who has granted medRxiv a license to display the preprint in perpetuity.

All rights reserved. No reuse allowed without permission.

104 humans when only using Vero E6 cell lines as a reference. This could mean that the actual

105 transmission risk would be lower than findings based on Vero E6 culture data and that

106 transmission-relevant infectious virus shedding is shorter and/or lower than what was

107 previously estimated. Furthermore, antigen-based rapid diagnostic tests, which have a lower

108 sensitivity than PCR but may detect infections with VLs as low as $6 \log _{10}$ RNAc/mL [10], would

109 thus be an even better at identifying infectious individuals than previously believed. Further

110 research is still needed to investigate the infectious doses of SARS-CoV-2 under real life

111 conditions. Even if the presence of such infectious virus is not enough to predict the

112 transmission risk, as multiple factors influence transmission, VL constitutes one of the most

113 important drivers of transmission [11].

114 As the infectious dose of SARS-CoV-2 still needs to be determined in vivo [12], and HAEs do

115 not completely recapitulate the in vivo situation, our study cannot be used to change existing

116 guidelines on isolation or discharge criteria. It nevertheless emphasizes the effect of the cell

117 lines used to culture the virus and thus supports the use of models that more closely reflect

118 the in vivo situation, such as HAE in air-liquid interface culture rather than conventional cell

119 lines, in order to better understand transmission risks of SARS-CoV-2 in patients.

120 Acknowledgments

121 We thank Catia Alvarez for excellent technical support and Erik Boehm for English proof

122 reading (Geneva Centre for Emerging Viral Diseases, Geneva University Hospitals, Geneva,

123 Switzerland).

\section{Funding}

125 This work was supported by the Private HUG Foundation, by the Pictet Charitable Foundation

126 and by the Swiss National Science Foundation (grant Nr. 196644, 196383). 
medRxiv preprint doi: https://doi.org/10.1101/2021.05.18.21257110; this version posted May 19, 2021. The copyright holder for this preprint (which was not certified by peer review) is the author/funder, who has granted medRxiv a license to display the preprint in perpetuity.

All rights reserved. No reuse allowed without permission.

\section{References}

1. Wölfel R, Corman VM, Guggemos W, et al. Virological assessment of hospitalized patients with COVID-2019. Nature 2020; 581(7809): 465-9.

2. Bullard J, Dust K, Funk D, et al. May 2020. Predicting infectious SARS-CoV-2 from diagnostic samples. Clin Infect Dis doi 10.

3. van Kampen JJ, van de Vijver DA, Fraaij PL, et al. Duration and key determinants of infectious virus shedding in hospitalized patients with coronavirus disease-2019 (COVID-19). Nature communications 2021; 12(1): 1-6.

4. Chu H, Chan JF-W, Yuen TT-T, et al. Comparative tropism, replication kinetics, and cell damage profiling of SARS-CoV-2 and SARS-CoV with implications for clinical manifestations, transmissibility, and laboratory studies of COVID-19: an observational study. The Lancet Microbe 2020; 1(1): e14-e23.

5. Chew T, Noyce R, Collins SE, Hancock MH, Mossman KL. Characterization of the interferon regulatory factor 3-mediated antiviral response in a cell line deficient for IFN production. Molecular immunology 2009; 46(3): 393-9.

6. Ren X, Glende J, Al-Falah M, et al. Analysis of ACE2 in polarized epithelial cells: surface expression and function as receptor for severe acute respiratory syndrome-associated coronavirus. Journal of general virology 2006; 87(6): 1691-5.

7. Baggio S, L'Huillier AG, Yerly S, et al. Severe Acute Respiratory Syndrome Coronavirus 2 (SARS-CoV-2) Viral Load in the Upper Respiratory Tract of Children and Adults With Early Acute Coronavirus Disease 2019 (COVID-19). Clinical Infectious Diseases 2020.

8. L'Huillier AG, Torriani G, Pigny F, Kaiser L, Eckerle I. Culture-competent SARS-CoV-2 in nasopharynx of symptomatic neonates, children, and adolescents. Emerging infectious diseases 2020; 26(10): 2494.

9. Essaidi-Laziosi M, Brito F, Benaoudia S, et al. Propagation of respiratory viruses in human airway epithelia reveals persistent virus-specific signatures. Journal of Allergy and Clinical Immunology 2018; 141(6): 2074-84.

10. Berger A, Nsoga MTN, Perez-Rodriguez FJ, et al. Diagnostic accuracy of two commercial SARS-CoV-2 Antigen-detecting rapid tests at the point of care in community-based testing centers. Plos one 2021; 16(3): e0248921.

11. Marks M, Millat-Martinez P, Ouchi D, et al. Transmission of COVID-19 in 282 clusters in Catalonia, Spain: a cohort study. The Lancet Infectious Diseases 2021.

12. Karimzadeh S, Bhopal R, Tien HN. Review of infective dose, routes of transmission, and outcome of COVID-19 caused by the SARS-CoV-2 Virus: comparison with other respiratory viruses. 2020. 
medRxiv preprint doi: https://doi.org/10.1101/2021.05.18.21257110; this version posted May 19, 2021. The copyright holder for this preprint (which was not certified by peer review) is the author/funder, who has granted medRxiv a license to display the preprint in perpetuity.

All rights reserved. No reuse allowed without permission.

A

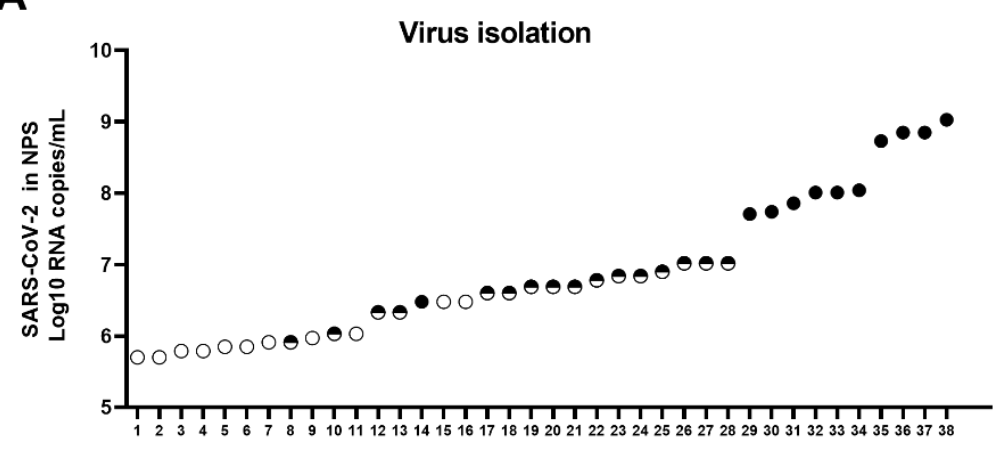

Samples
B

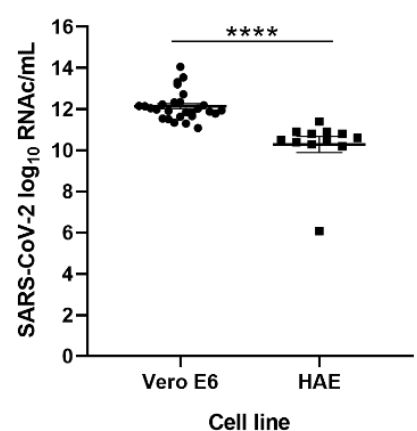

166

Figure 1. Comparative virus isolation in Vero E6 versus reconstituted human primary airway epithelial cells (HAE). A Comparative virus isolation success in Vero E6 versus HAE.

Comparing baseline to $6 \mathrm{dpi}$, the success of isolation was determined and presented as follow: ' $O$ : unsuccessful isolation; $\bullet$ : successful isolation only in Vero E6; $\bullet$ : successful isolation Vero E6 and HAE. B. SARS-CoV-2 viral loads 6 dpi after successful isolation in cell culture supernatant (Vero E6) and apical washes (HAE). Statistical significance was calculated using t test $(* * * *: p<0.0001)$. 
medRxiv preprint doi: https://doi.org/10.1101/2021.05.18.21257110; this version posted May 19, 2021. The copyright holder for this preprint (which was not certified by peer review) is the author/funder, who has granted medRxiv a license to display the preprint in perpetuity.

All rights reserved. No reuse allowed without permission.

\begin{tabular}{|c|c|c|c|c|}
\hline \multirow[t]{2}{*}{ Sample ID } & \multirow[t]{2}{*}{ SARS-CoV-2 log10 RNA copies/mL } & \multirow[t]{2}{*}{ Days post symptoms } & \multicolumn{2}{|c|}{ SARS-CoV-2 isolation } \\
\hline & & & Vero E6 & HAE \\
\hline 1 & 5.7 & 3 & - & - \\
\hline 2 & 5.7 & 4 & - & - \\
\hline 3 & 5.8 & 4 & - & - \\
\hline 4 & 5.8 & 1 & - & - \\
\hline 5 & 5.8 & 5 & - & - \\
\hline 6 & 5.8 & 1 & - & - \\
\hline 7 & 5.9 & 4 & - & - \\
\hline 8 & 5.9 & 3 & + & - \\
\hline 9 & 6.0 & 0 & - & - \\
\hline 10 & 6.0 & 3 & + & - \\
\hline 11 & 6.0 & 5 & - & - \\
\hline 12 & 6.3 & 2 & + & + \\
\hline 13 & 6.3 & 2 & + & - \\
\hline 14 & 6.5 & 1 & + & + \\
\hline 15 & 6.5 & 1 & - & - \\
\hline 16 & 6.5 & 0 & - & - \\
\hline 17 & 6.6 & 2 & + & - \\
\hline 18 & 6.6 & 1 & + & - \\
\hline 19 & 6.7 & 4 & + & - \\
\hline 20 & 6.7 & 4 & + & - \\
\hline 21 & 6.7 & 1 & + & - \\
\hline 22 & 6.8 & 2 & + & - \\
\hline 23 & 6.8 & 1 & + & - \\
\hline 24 & 6.8 & 3 & + & - \\
\hline 25 & 6.9 & 3 & + & - \\
\hline 26 & 7.0 & 4 & + & - \\
\hline 27 & 7.0 & 0 & + & - \\
\hline 28 & 7.0 & 4 & + & - \\
\hline 29 & 7.7 & 3 & + & + \\
\hline 30 & 7.7 & 4 & + & + \\
\hline 31 & 7.9 & 5 & + & + \\
\hline 32 & 8.0 & 1 & + & + \\
\hline 33 & 8.0 & 0 & + & + \\
\hline 34 & 8.0 & 3 & + & + \\
\hline 35 & 8.7 & 4 & + & + \\
\hline 36 & 8.8 & 3 & + & + \\
\hline 37 & 8.8 & 3 & + & + \\
\hline 38 & 9.0 & 1 & + & + \\
\hline
\end{tabular}

176 Table S1. Sample characteristics 
A

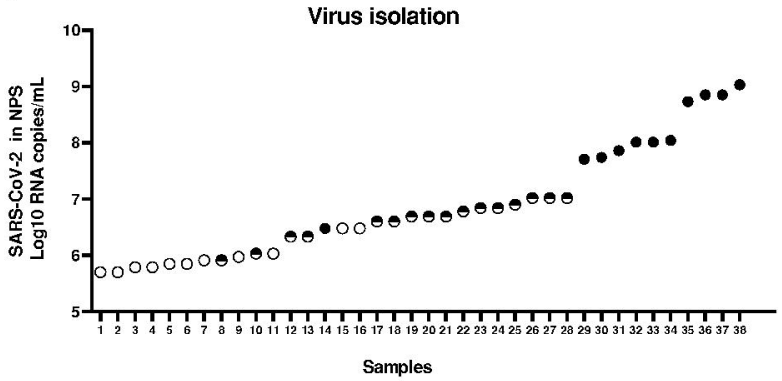

B

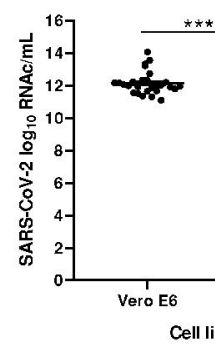

